\title{
LEGIBILIDADE DA LEGISLAÇÃO PREVIDENCIÁRIA NO CONTEXTO DA LEI DE ACESSO À INFORMAÇÃO
}

\author{
LEGIBIDAD LA LEGISLACIÓN SEGURO SOCIAL \\ BAJO LA LEY DE ACCESO A LA INFORMACIÓN
}

\author{
Andréia Gonçalves Silva - andreiabiblio@uol.com.br \\ Doutora em Ciência da Informação pela Universidade de São Paulo \\ (USP). Docente da Faculdade de Biblioteconomia e Ciência da \\ Informação da Fundação Escola de Sociologia e Política de São \\ Paulo (FESPSP). \\ Marilda Lopes Ginez de Lara - larama@usp.br \\ Doutora em Ciências da Comunicação pela Universidade de São \\ Paulo (USP). Professora da USP.
}

\begin{abstract}
RESUMO
Introdução: A Lei de Acesso à Informação Pública (LAI) regulamenta o direito à informação estabelecido pela Constituição Federal de 1988, exigindo que os órgãos governamentais garantam o direito de acesso à informação pública mediante procedimentos objetivos e ágeis, de forma transparente, clara e em linguagem de fácil compreensão. Parte-se do pressuposto de que as leis produzidas pelo Legislativo podem ser consideradas "informação pública" e por isso devem ser disponibilizadas ao cidadão num formato simples e acessível.

Objetivo: Investigar as iniciativas que divulgam a legislação previdenciária numa linguagem acessível e de fácil assimilação pelo cidadão, conforme dispõe a Lei de Acesso à Informação.

Metodologia: Analisou-se o conteúdo das cartilhas e folders disponibilizados no portal do Ministério da Previdência Social, comparando-o com os dispositivos da Lei 8.213/91, que dispõe sobre os planos de benefícios da previdência social e observando se essas publicações são editadas conforme disposições da LAI.

Resultados: De uma forma geral, a redação e os recursos ilustrativos dos textos simplificados - cartilhas e folders - facilitam a compreensão da informação previdenciária pelo cidadão.

Conclusão: Conclui-se que as publicações estudadas seguem as recomendações da LAI, com textos que se caracterizam pela objetividade, clareza e uso de linguagem acessível.
\end{abstract}


Palavras-chave: Legislação previdenciária. Lei de Acesso à Informação. Cartilhas. Folders.

\section{INTRODUÇÃO}

O acesso à informação é um direito fundamental reconhecido pela Constituição Federal de 1998 (BRASIL, 1988). Com a publicação da Lei de Acesso à Informação (LAI), Lei 12.527, de 18 de novembro de 2011 (BRASIL, 2011b), o acesso à informação foi regulamentado e passou-se a exigir que as informações sejam disponibilizadas de forma transparente, clara e em linguagem de fácil compreensão. De acordo com dispositivos da LAI, o cidadão pode requerer informação contida em registros ou documentos produzidos ou acumulados pelos entes governamentais. Partindo deste princípio, seria recomendável que os textos legislativos e atos administrativos estivessem aí incluídos, sendo disponibilizados à população em linguagem de fácil compreensão.

Observa-se, no entanto, que na práxis os legisladores utilizam estrutura textual, linguagem e redação que se distanciam do entendimento do público em geral, mesmo nas leis que regulamentam questões que interferem diretamente na vida do cidadão, como, por exemplo, as leis que regem o direito à seguridade e previdência social (leis 8.212/91 e 8213/91). O artigo 12 da Lei 8.212 determina que as pessoas físicas são seguradas obrigatórios da previdência social, categorizando-as em empregados e contribuintes individuais. $\mathrm{O}$ inciso que dispõe sobre o contribuinte individual traz na alínea a, a seguinte disposição:

São segurados obrigatórios da Previdência Social as seguintes pessoas físicas: [...]

$\mathrm{V}$ - como contribuinte individual:

a) a pessoa física, proprietária ou não, que explora atividade agropecuária, a qualquer título, em caráter permanente ou temporário, em área superior a 4 (quatro) módulos fiscais; ou, quando em área igual ou inferior a 4 (quatro) módulos fiscais ou atividade pesqueira, com auxílio de empregados ou 
por intermédio de prepostos; ou ainda nas hipóteses dos $\S \S 10$ e 11 deste artigo (BRASIL, 1991a, grifo nosso).

A redação contém conceitos que fazem parte do léxico comum, sendo compreensíveis ao cidadão, tais como: pessoa física, atividade agropecuária, caráter permanente ou temporário, atividade pesqueira, etc. Mas ao mesmo tempo, a alínea traz expressões que podem prejudicar a compreensão. $O$ cidadão pode ter dificuldade para entender o que significam as expressões a qualquer título, área superior a 4 (quatro) módulos fiscais ou por intermédio de prepostos. Até mesmo o termo contribuinte individual que significa "contribuinte que exerce atividade de forma autônoma" pode ser desconhecido pelos cidadãos.

Tal fenômeno ocorre também na Lei 8.213. A título de exemplo, observa-se a redação do parágrafo segundo, do artigo 17, que trata das inscrições dos segurados e dos seus dependentes.

$\S 2^{\circ} \mathrm{O}$ cancelamento da inscrição do cônjuge se processa em face de separação judicial ou divórcio sem direito a alimentos, certidão de anulação de casamento, certidão de óbito ou sentença judicial, transitada em julgado (BRASIL, 1991b, grifo nosso).

Talvez o cidadão consiga compreender que o cancelamento da inscrição do marido ou da esposa ocorra com a separação judicial ou divórcio, quando não há pensão alimentícia, ou com a apresentação da certidão de anulação de casamento, certidão de óbito ou sentença judicial. Agora, quanto à expressão jurídica transitada em julgado, provavelmente haverá incompreensão.

As expressões técnicas, a redação rebuscada e os conceitos incompreensíveis para o público não especialista são características comuns da redação jurídica. No que se refere à redação legislativa, é necessário que o legislador entenda que o texto por ele produzido será comunicado a uma coletividade que fará uso da mensagem ali veiculada. O texto legislativo define direitos, regras, comportamentos e obrigações que são impostas à população. Nesse sentido, defendem-se 
iniciativas que, seguindo as diretrizes da Lei de Acesso à Informação, ofereçam acesso à informação de interesse coletivo numa linguagem mais acessível e de fácil compreensão, principalmente das leis que regulam os direitos sociais do cidadão.

As leis previdenciárias se inserem neste contexto, são de interesse coletivo e asseguram direitos sociais. A Lei $8.212 / 91$ regulamenta a organização da seguridade social e a Lei 8.213/91 dispõe sobre os planos de benefícios da previdência social. Num linguajar mais próximo do cidadão, a primeira apresenta diretrizes de como são custeados e mantidos os benefícios destinados a assegurar o direito à saúde, à previdência social e à assistência social. E a segunda apresenta quais sãos os benefícios que serão pagos ao cidadão quando ele estiver incapacitado para garantir o seu próprio sustento e o de sua família. Desemprego, acidente de trabalho, idade avançada, tempo de trabalho atingido, auxílio doença, prisão ou morte do responsável pelo sustento da família, entre outros, são eventos que garantem o direito do cidadão a receber um benefício social por certo tempo ou por tempo indeterminado. Sendo assim, é importante que ele tenha acesso e compreenda as normas que regem tais benefícios para, quando necessário, procurar os órgãos competentes e lutar pelos seus direitos.

É o que atesta a Cartilha Acesso à Informação Pública, elaborada pela Controladoria-Geral da União, ao afirmar que "o cidadão bem informado tem melhores condições de conhecer e acessar outros direitos essenciais, como saúde, educação e benefícios sociais" e conhecerá melhor os seus direitos (BRASIL, 2011a, p. 8).

A igualdade de todos perante a lei começa com a igualdade de acesso à informação. Se o conhecimento é a informação trabalhada, o indivíduo só alcançará o status de conhecedor dos seus direitos se deles tiver conhecimento e se eles Ihe forem informados.

Neste sentido, o desafio que se descortina é como manter o cidadão bem informado, já que o acesso à informação depende de questões pragmáticas e cognitivas, como por exemplo, a 
disponibilização da lei pelo órgão governamental de forma que ela possa ser plenamente assimilada pelo cidadão. Registre-se que o grau de conhecimento do cidadão brasileiro em relação à informação legislativa é pequeno", daí a importância de ações que se preocupem com o "como a informação será assimilada pelo cidadão".

Na prática, a garantia efetiva do direito à informação requer não apenas a divulgação proativa por parte dos órgãos públicos (a obrigação de publicação), mas também a solicitação e o recebimento por qualquer pessoa de quaisquer informações em poder dos órgãos públicos, sujeito às exceções. Isso, por sua vez, exige que sejam criados procedimentos claros a serem seguidos pelos órgãos, para processar pedidos de informação (MENDEL, 2009, p. 38).

O objetivo deste artigo é investigar iniciativas que divulgam a legislação previdenciária numa linguagem acessível para o cidadão, conforme dispõe a Lei de Acesso à Informação - LAI. Para tanto, pretende-se analisar o conteúdo das publicações produzidas pelo Ministério da Previdência Social, órgão responsável pela administração da previdência social.

Se o acesso à informação é um direito fundamental, é indispensável que a sociedade civil, os acadêmicos e os órgãos governamentais criem mecanismos que apliquem as recomendações da LAI, principalmente no que se refere à disponibilização da informação de forma transparente, clara e em linguagem de fácil compreensão. A Ciência da informação, enquanto disciplina responsável pelos fenômenos que envolvem a criação, estruturação, recuperação e acesso à informação, deve contribuir com as iniciativas que visam a garantir o acesso à informação para todos os cidadãos brasileiros.

\footnotetext{
${ }^{1}$ Em pesquisa realizada em 1997, no Rio de Janeiro, o historiador José Murilo de Carvalho entrevistou várias cidadãos e pediu que cada um citasse três direitos constitucionais que considerasse mais importantes. As respostas demonstram a ignorância dos entrevistados em mencionar um só direito. Somente $12 \%$ dos entrevistados, de uma população quase toda alfabetizada, souberam mencionar um direito civil, em comparação 56,7\% não conseguiram citar nenhum (CARVALHO, 2000, p. 108).
} 


\section{LEI DE ACESSO À INFORMAÇÃO PÚBLICA}

No biênio 2002-2003, a Organização das Nações Unidas para a Educação, a Ciência e a Cultura (UNESCO) iniciou a redação de diretrizes políticas para assessorar os Estados no desenvolvimento e promoção da informação de domínio público. Os dirigentes e idealizadores da ação entendiam que uma das principais metas de qualquer sociedade é o fortalecimento dos cidadãos, por meio do uso da informação e do conhecimento, e que as informações de domínio público poderiam ser disseminadas pela internet, por meio de bibliotecas, empresas ou escolas. A disseminação da informação de domínio público na internet contribuiria para o desenvolvimento econômico e social dos países que adotassem políticas de acesso à informação pública, por ser a internet uma rede que transcende as fronteiras das políticas nacionais. A ideia era criar governo e administração pública transparentes, pois quanto mais informações disponíveis, menor seria a possibilidade de ocultação de atos ilegais, corrupção e má administração. O documento criado estabelecia que a concretização dos ideais de transparência e promoção do acesso e utilização da informação de domínio público, ocorreria por meio da adoção de uma lei nacional de liberdade de informação que assegurasse ao cidadão 0 acesso à informação produzida pelo governo e que não estivesse rotineiramente disponível. $O$ objetivo era prover acesso universal e diminuir a lacuna entre os ricos e os pobres em informação, expandindo a quantidade e qualidade de informação de domínio público (UHLIR, 2006, p. 13-34). Com estas diretrizes a UNESCO e seus dirigentes acreditavam que a publicação de informações públicas poderia trazer consideráveis benefícios para o cidadão. 


\begin{abstract}
A disseminação aberta e irrestrita da informação do setor público também promove a melhoria da saúde e segurança públicas e do bem-estar social geral, à medida que os cidadãos se tornem mais bem informados para tomar decisões sobre sua vida cotidiana, seu ambiente e seu futuro. Sem dúvida, há uma vasta gama de objetivos sociais que servem de base para o provimento de conteúdos públicos (UHLIR, 2006, p. 30).
\end{abstract}

A informação pública pode ser configurada como toda informação produzida pelos órgãos da Administração Pública. A Presidência da República, os Ministérios, as Secretarias, as Assembleias Legislativas, as Câmaras Municipais, os Tribunais, as Empresas e Autarquias Públicas, entre outros órgãos governamentais, produzem informação que é de domínio e de interesse público e pertence ao patrimônio público.

Depois de quase uma década, as diretrizes da UNESCO chegaram ao Brasil com a LAI (Lei 12.527/20112), que garante ao cidadão a possibilidade de solicitar e obter informações produzidas pelos órgãos públicos integrantes dos Poderes Executivo, Legislativo e Judiciário e pelas autarquias e empresas públicas. A promulgação da LAI é uma contribuição significativa para a democratização do acesso à informação de uma forma unificada e simplificada.

De acordo com os dispositivos da lei, é dever dos órgãos e entidades públicas divulgar informações de interesse coletivo em seus sites oficiais da internet, independente de requerimento. Por sua vez, os sites devem conter ferramenta de pesquisa de conteúdo que permita acesso à informação de forma objetiva, transparente e em linguagem de fácil compreensão.

O cidadão pode requerer informações dos órgãos federados sem precisar justificar interesse ou legitimidade. Ao contrário da cultura de segredo que pregava que o cidadão só poderia solicitar informações relacionadas aos seus interesses diretos ou que ele não estava

\footnotetext{
${ }^{2}$ Regulamentada na esfera federal pelo Decreto 7.724 de 16 de maio de 2012 (BRASIL, 2011b).
} 
preparado para exercer o direito de acesso à informação, a cultura de acesso à informação promovida pela LAI defende que a demanda do cidadão é sempre legítima e que as informações públicas podem ser solicitadas sem necessidade de justificativa (BRASIL, 2011a, p. 12-13).

Como afirma Jardim (2012, p. 7), "o cidadão está no epicentro da LAI. A sua lógica político-jurídica é a garantia de acesso à informação ao cidadão pelo Estado".

Deste modo, para que o acesso do cidadão seja garantido, o artigo 9 da Lei prevê a criação, em todos os órgãos e entidades do poder público, de um Serviço de Informações ao Cidadão (SIC). Esse serviço tem a função de atender e orientar o público quanto ao acesso às informações, informar sobre a tramitação de documentos nas suas respectivas unidades e protocolar documentos e requerimentos de acesso à informação. O SIC deve fornecer informações gratuitas, salvo cópias de documentos, e não deve exigir nenhuma justificação, exceto a identificação do requerente e a especificação da informação requerida. O órgão público é compelido a autorizar ou conceder o acesso imediato à informação disponível. Caso o pedido não seja atendido prontamente deverá, num prazo não superior a vinte dias, comunicar a data, local e modo para se realizar a consulta, efetuar a reprodução ou obter a certidão; indicar as razões de fato ou de direito da recusa, total ou parcial, do acesso pretendido; ou comunicar que não possui a informação.

O artigo 68 do Decreto 7.724/2012 (BRASIL, 2012a) dispõe que o monitoramento da LAI, no âmbito do Executivo Federal, será de responsabilidade da Controladoria-Geral da União (CGU). No tocante à implantação e monitoramento entre os órgãos estaduais e municipais, o artigo 47 da LAl estabelece que cabe aos Estados e Municípios, em legislação própria, definir regras específicas quanto à criação de serviços de informação ao cidadão. Neste sentido, impõe-se frisar a responsabilidade solidária entre as esferas federal, estadual e municipal 
no que concerne ao cumprimento do disposto na lei e no decreto regulamentador.

São conferidas também a CGU, a consolidação e publicação de informações estatísticas como a quantidade de pedidos de acesso à informação recebidos. O relatório estatístico disponibilizado no site do Sistema Eletrônico do Serviço do Cidadão (BRASIL, 2015) indica que, desde a vigência da LAI, que ocorreu em maio de 2012, até março de 2014, foram realizados 157.158 pedidos de informação. Deste total, 3.302 estão relacionados a questões de previdência social. O Instituto Nacional de Seguro Social (INSS), autarquia vinculada ao Ministério da Previdência Social, foi o segundo órgão mais demandado em pedidos de informações ${ }^{3}$.

Por meio de contato com o Serviço de Informação ao Cidadão (e$\mathrm{SIC}$ ), buscou-se investigar quais eram os tipos de informação mais solicitadas ao INSS, porém não se obteve êxito. Segundo a resposta disponibilizada, a CGU não possui detalhamento dos tipos de pedidos feitos ao INSS, uma vez que estes são variados. São constantes as solicitações relacionadas a benefícios (pagamentos, valores, decisões e recursos) e recolhimentos previdenciários (extrato previdenciário e dados cadastrais). De uma forma geral, ambos os pedidos são indeferidos por serem informações pessoais não passíveis de fornecimento pelo e-SIC e os solicitantes são orientados a buscar os canais de atendimento do INSS ${ }^{4}$.

Com base no acima exposto, observa-se que há um movimento do cidadão no sentido de sanar suas dúvidas sobre questões previdenciárias. Nesse diapasão é louvável a iniciativa de órgãos públicos, como o Ministério da Previdência Social, que disponibiliza, em

${ }^{3}$ Conforme o 1ํㅡㄹ Balanço da Lei de Acesso à Informação no Poder Executivo Federal (16 de maio a 31 de dezembro de 2012. (BRASIL, 2015).

${ }^{4}$ Pedido de informação no 37400.000939/2014-85 realizado em 11 fev. 2014. Resposta obtida em 17 fev. 2014. 
seu portal, publicações que apresentam quais são os benefícios da previdência social em uma linguagem acessível.

\section{LEGISLAÇÃO PREVIDENCIÁRIA}

Após longos anos de trabalho ou quando se adquire uma idade avançada, o trabalhador deseja descansar e ter recursos financeiros que garantam sua sobrevivência e a de sua família.

Para garantir o direito aos benefícios da previdência social, além da contribuição mensal, é necessário que o trabalhador atenda a várias condições previstas em lei. É neste momento que muitos enfrentam contratempos, sendo necessária, em alguns casos, a intervenção do Poder Judiciário. Daí a importância de se disponibilizar informações sobre a legislação previdenciária, de modo a permitir que o trabalhador saiba pleitear seus direitos junto aos órgãos vinculados ao Regime da Previdência Social.

Ao longo da história da humanidade, as instituições sempre se preocuparam com os infortúnios que podem ocorrer quando o trabalhador é impossibilitado de garantir o seu próprio sustento ou o de sua família, seja pela chegada da idade, problemas de saúde ou acidentes de trabalho.

No Brasil o conceito de previdência surgiu pela primeira vez com a Lei Eloy Chaves (Decreto 4.682, 24/01/1923) que criava as Caixas de Aposentadorias e Pensões para os ferroviários de todo o território nacional. As caixas garantiam aposentadoria por invalidez, pensão por morte e assistência médica. Posteriormente, os benefícios da Lei Eloy foram estendidos para os trabalhadores dos serviços portuários, marítimos, telegráficos, de luz, dos bondes e bancários, por meio de leis próprias. Com o passar do tempo, as caixas de aposentadoria e pensões foram agrupadas em "Institutos de Aposentadoria e Pensões". Em 1966, todos os institutos foram unificados pelo Instituto Nacional de Previdência Social (INPS), o embrião do atual INSS (MARTINS, 2010). 
Atualmente, o direito à assistência previdenciária está garantido na Constituição Federal de 1988. O artigo 194 dispõe sobre a seguridade social, atestando que ela compreende um conjunto de ações da iniciativa privada e do Estado, a fim de assegurar os direitos à saúde, à previdência e à assistência social. Já o artigo 201 dispõe que a previdência social será organizada sob a forma de regime geral, de caráter contributivo e com filiação obrigatória e estabelece as coberturas que o regime da previdência assegura aos contribuintes.

Além dos textos constitucionais, existem diversos atos normativos que estabelecem regras previdenciárias. No entanto, os principais são as leis 8.212/91 (trata do custeio da seguridade social) e 8.213/91 (apresenta o rol de benefícios que podem ser concedidos).

Os benefícios garantidos pelo texto constitucional e ratificados pela Lei 8.213/1991 são: cobertura de eventos de doença, invalidez, morte e idade avançada; proteção à maternidade; proteção ao trabalhador em situação de desemprego involuntário; salário família e auxílio reclusão para os dependentes dos segurados de baixa renda e pensão por morte do segurado.

Na Lei 8.213 (BRASIL, 1991b) os benefícios são estabelecidos no artigo 18, que divide as prestações oferecidas pelo Regime Geral de Previdência Social em três categorias:

- quanto ao segurado: aposentadoria por invalidez, aposentadoria por idade, aposentadoria por tempo de serviço, aposentadoria especial, auxílio doença, salário-família, salário maternidade, auxílio-acidente;

- quanto aos dependentes: pensão por morte, auxílio-reclusão;

- quanto ao segurado e dependente: serviço social e reabilitação profissional.

\section{PROCEDIMENTOS METODOLÓGICOS}

A definição do corpus da presente pesquisa envolveu o estudo da legislação previdenciária, a análise da Lei 8.213/91 e o exame das 
publicações - cartilhas e folders - disponibilizadas no portal do Ministério da Previdência Social (endereço eletrônico: www.previdencia.gov.br/). As publicações foram pesquisas no período de fevereiro de 2013 a fevereiro de 2014.

Das cartilhas analisadas selecionou-se para a concretização da pesquisa a intitulada Previdência social. Com ela, você tem muito mais tranquilidade para sua vida e seu futuro. A escolha desta publicação, que foi editada em 2012, justifica-se porque em sua apresentação relata-se que ainda são muitas as dúvidas sobre os benefícios previdenciários, tanto para quem já está perto de se aposentar, como para os mais jovens que um dia terão que parar de trabalhar. Partindo desse pressuposto, os responsáveis pela publicação apresentam de forma clara e simples quais são os benefícios da previdência social, a partir da história de pessoas que já são beneficiárias do INSS.

Os folders selecionados também possuem linguagem clara e simples. Não há data de publicação explícita em nenhum deles. Os temas abordados são auxílio-doença, salário-família, saláriomaternidade, pensão por morte, auxílio-reclusão e auxílio-acidente.

\section{O ACESSO À INFORMAÇÃO PREVIDENCIÁRIA NO CONTEXTO DA LAI}

A informação previdenciária, por ser de utilidade pública e interferir diretamente na vida do cidadão, se insere no âmbito da LAI. Observa-se que o sistema previdenciário brasileiro passou por várias reformas e há informações que podem passar despercebidas para o cidadão.

Com o intuito de investigar como a legislação previdenciária é disponibilizada em meios alternativos, que não sejam o próprio texto da lei, foram analisadas algumas publicações do Ministério da Previdência Social, a fim de verificar se elas incorporam os preceitos defendidos pela LAI. 
O resultado da análise é apresentado em quadros. Na coluna da esquerda são exibidos os dispositivos da Lei 8.213/91 e na coluna da direita é demonstrada a informação previdenciária de forma simplificada.

No primeiro quadro são apresentadas informações sobre a aposentadoria por invalidez. As disposições deste direito estão asseguradas nos artigos 42 a 47 da Lei 8.213/91. O artigo 42 diz que a aposentadoria por invalidez, quando cumprida a carência exigida, será devida ao segurado que for considerado incapaz para o exercício de atividade que the garanta a subsistência. A definição do que é a aposentadoria por invalidez não aparece logo no início do artigo. A carência exigida não é mencionada e, para obter tal informação, o cidadão deve consultar o inciso II do artigo 25 da referida lei. Ademais, a inversão de frase (que é própria da redação jurídica), pode comprometer a assimilação e compreensão. Já o texto da cartilha traz, logo no início e em linguagem acessível, o que é a aposentadoria por invalidez. Menciona a necessidade da perícia médica e já informa o prazo de carência. A figura do homem na cadeira de rodas e a disposição do texto contribuem para o entendimento das disposições dos artigos $42 \mathrm{e}$ 43 , com seus respectivos parágrafos. 
Quadro 1 - Aposentadoria por invalidez

\begin{tabular}{|c|c|c|}
\hline $\begin{array}{c}\text { Informação previdenciária } \\
\text { originária da Lei } 8.213 / 91\end{array}$ & $\begin{array}{r}\text { Informação pr } \\
\text { de texto }\end{array}$ & $\begin{array}{l}\text { lenciária originária } \\
\text { implificados }\end{array}$ \\
\hline 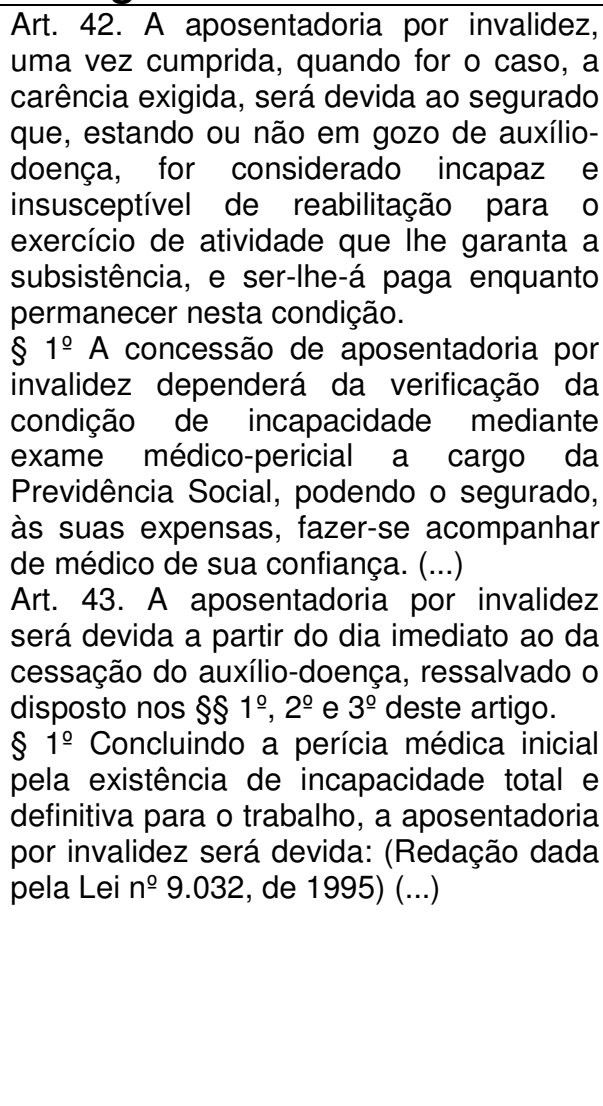 & 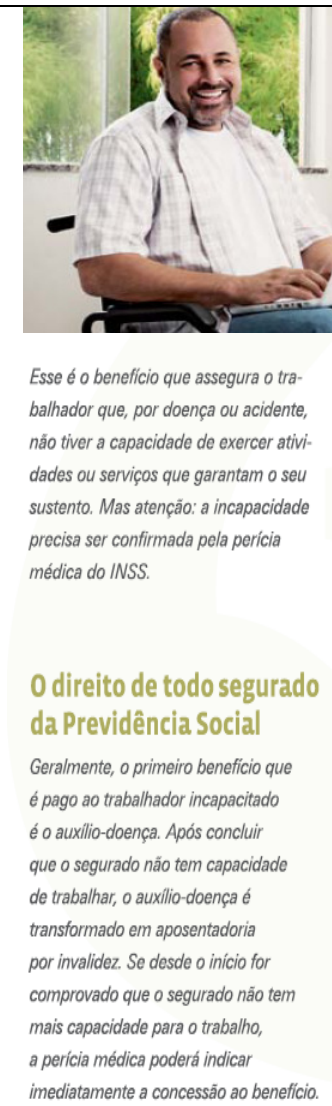 & 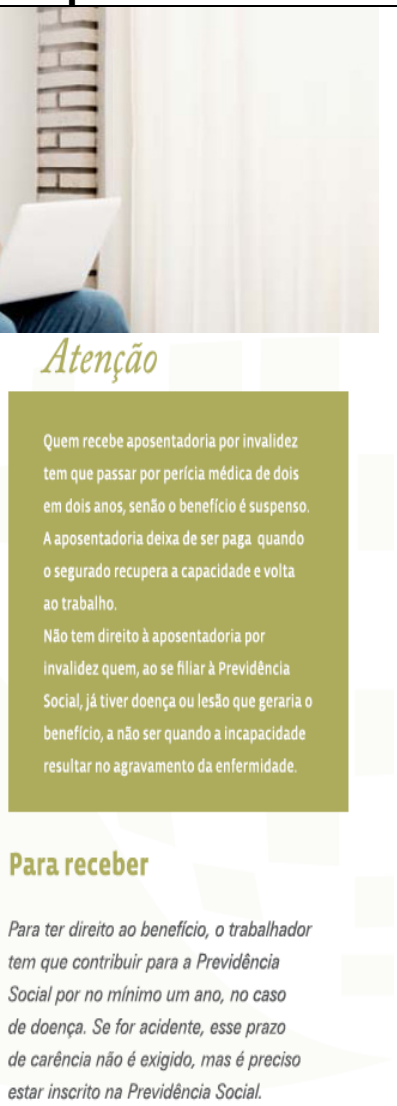 \\
\hline
\end{tabular}

Fonte: Brasil (2012b, p. 14).

O próximo quadro apresenta as disposições da aposentadoria por idade que é regulamentada pelos artigos 48, 49 e 50 da já mencionada Lei 8.213/91. A redação do caput do artigo 48 não traz nenhum empecilho no que se refere à compreensão. Já a disposição do parágrafo $1^{\circ}$, que estabelece as condições para a aposentadoria do trabalhador rural, não está muito clara. O texto faz menção a incisos e alíneas do artigo 11 e isto pode dificultar a compreensão. Por outro lado, o exemplo da cartilha apresenta, já na disposição do texto, nas ilustrações e no método de redação um contexto que favorece o entendimento. Dizer "que a idade para se aposentar varia de acordo com o sexo. Enquanto o homem pode entrar com o pedido aos 65 anos, a mulher deve contar com 60 anos" é mais compreensível para o 
cidadão não especialista que dizer "a aposentadoria por idade será devida ao segurado que, cumprida a carência exigida nesta Lei, completar 65 (sessenta e cinco) anos de idade, se homem, e 60 (sessenta), se mulher". A explicação da aposentadoria do trabalhador rural segue a mesma linha de clarificação e é apresentada ainda uma curiosidade sobre o surgimento da aposentadoria por idade.

Quadro 2 - Aposentadoria por idade

\begin{tabular}{|c|c|}
\hline $\begin{array}{l}\text { Informação previdenciária } \\
\text { originária da Lei } 8.213 / 91\end{array}$ & $\begin{array}{c}\text { Informação previdenciária originária de } \\
\text { textos simplificados }\end{array}$ \\
\hline $\begin{array}{l}\text { Art. 48. A aposentadoria por idade será } \\
\text { devida ao segurado que, cumprida a } \\
\text { carência exigida nesta Lei, completar } \\
65 \text { (sessenta e cinco) anos de idade, se } \\
\text { homem, e } 60 \text { (sessenta), se mulher. } \\
\text { (Redação dada pela Lei no 9.032, de } \\
1995 \text { ) } \\
\S 1^{\circ} \text { Os limites fixados no caput são } \\
\text { reduzidos para sessenta e cinqüenta e } \\
\text { cinco anos no caso de trabalhadores } \\
\text { rurais, respectivamente homens e } \\
\text { mulheres, referidos na alínea a do } \\
\text { inciso I, na alínea g do inciso V e nos } \\
\text { incisos VI e VII do art. 11. (Redação } \\
\text { dada pela Lei no } 9.876 \text {, de 1999) }\end{array}$ & $\begin{array}{l}\text { Esse beneficicio é uma das primeiras } \\
\text { garantias das quais o trabalhador teve } \\
\text { direito. Nela, basta completar a idade e } \\
\text { ter contribuido para a Previdência So- } \\
\text { cial por } 180 \text { meses, ou seja, } 15 \text { anos, } \\
\text { para receber o beneficicio. Com a con- } \\
\text { cessão da aposentadoria, o trabalhador } \\
\text { passa a receber uma remuneraçấo fixa. } \\
\text { Quem tem direito } \\
\text { A idade para se aposentar varia de } \\
\text { acordo com o sexo. Enquanto o homem } \\
\text { pode entrar com o pedido aos } 65 \text { anos, } \\
\text { a mulher deve contar } 60 \text { anos para } \\
\text { conseguir ter direito ao beneficioio. Os } \\
\text { trabalhadores rurais podem pedir apo- } \\
\text { sentadoria por idade com cinco anos a } \\
\text { menos: a partir dos } 60 \text { anos, homens, } \\
\text { e a partir dos } 55 \text { anos, mulheres. Nesse } \\
\text { caso, têm de provar, com documentos, } \\
180 \text { meses (15 anos) de atividade rural. }\end{array}$ \\
\hline
\end{tabular}

Fonte: Brasil (2012b, p. 10).

A aposentadoria por tempo de contribuição, benefício do quadro 3, substituiu a aposentadoria por tempo de serviço após a publicação da Emenda Constitucional n 20, de 15 de dezembro de 1998. Observa-se que a redação da lei traz o tempo de 25 anos para mulher e 30 anos para o homem, pois ela é anterior a emenda. Já a cartilha traz a informação atualizada: 30 anos para a mulher e 35 para os homens. Se o contribuinte consultar apenas o texto da lei obterá informação desatualizada. No que se refere à acessibilidade de entendimento, a 
redação do artigo 52 está clara. Já as disposições do caput e incisos do artigo 53 requerem um pouco mais de atenção para serem compreendidos. A cartilha não simplificou essas informações, não deixando claro qual é o valor do salário de contribuição de cada segurado. Todavia, mencionou os procedimentos e documentos necessários para se obter o benefício.

\section{Quadro 3 - Aposentadoria por tempo de contribuição}

\begin{tabular}{|c|c|}
\hline $\begin{array}{c}\text { Informação previdenciária } \\
\text { originária da Lei } 8.213 / 91\end{array}$ & $\begin{array}{c}\text { Informação previdenciária orig } \\
\text { de textos simplificados }\end{array}$ \\
\hline $\begin{array}{l}\text { Art. 52. A aposentadoria por tempo de } \\
\text { serviço será devida, cumprida a carência } \\
\text { exigida nesta Lei, ao segurado que } \\
\text { completar } 25 \text { (vinte e cinco) anos de } \\
\text { serviço, se do sexo feminino, ou } 30 \\
\text { (trinta) anos, se do sexo masculino. } \\
\text { Art. } 53 \text {. A aposentadoria por tempo de } \\
\text { serviço, observado o disposto na Seção } \\
\text { III deste Capítulo, especialmente no art. } \\
33 \text {, consistirá numa renda mensal de: I - } \\
\text { para a mulher: } 70 \% \text { (setenta por cento) } \\
\text { do salário-de-benefício aos } 25 \text { (vinte e } \\
\text { cinco) anos de serviço, mais } 6 \% \text { (seis por } \\
\text { cento) deste, para cada novo ano } \\
\text { completo de atividade, até o máximo de } \\
100 \% \text { (cem por cento) do salário-de- } \\
\text { benefício aos } 30 \text { (trinta) anos de serviço; } \\
\text { II - para o homem: } 70 \% \text { (setenta por } \\
\text { cento) do salário-de-benefício aos } 30 \\
\text { (trinta) anos de serviço, mais } 6 \% \text { (seis } \\
\text { por cento) deste, para cada novo ano } \\
\text { completo de atividade, até o máximo de } \\
100 \% \text { (cem por cento) do salário-de- } \\
\text { benefício aos } 35 \text { (trinta e cinco) anos de } \\
\text { serviço. }\end{array}$ & 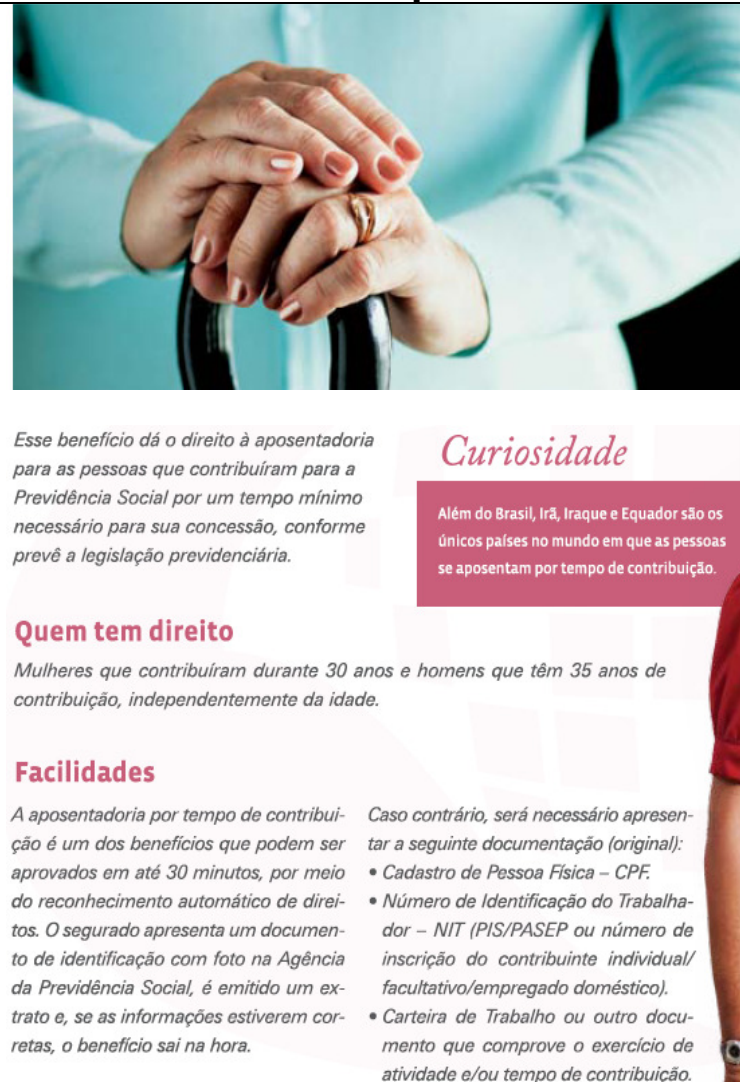 \\
\hline
\end{tabular}

Fonte: Brasil (2012b, p. 12).

Regulamentam a aposentadoria especial, próximo benefício a ser analisado, os artigos 57 e 58 da Lei 8.213/91. O caput e os incisos do dito artigo, de uma forma geral, possuem redação clara, embora sejam prolixos e mencionem outros dispositivos legislativos. A redação da cartilha no tópico "quem tem direito" está clara e objetiva. O redator conseguiu unir informações do caput e parágrafo $4^{\circ}$ do artigo 57 numa 
única frase, trazendo também, no tópico "Atenção", informações sobre quem pode obter os benefícios da aposentadoria especial. A ilustração da moça manipulando substâncias que podem ser nocivas para a integridade física contribui com a assimilação da informação.

\section{Quadro 4-Aposentadoria especial}

\section{Informação previdenciária originária da Lei 8.213/91}

Art. 57. A aposentadoria especial será devida, uma vez cumprida a carência exigida nesta Lei, ao segurado que tiver trabalhado sujeito a condições especiais que prejudiquem a saúde ou a integridade física, durante 15 (quinze), 20 (vinte) ou 25 (vinte e cinco) anos, conforme dispuser a lei. (Redação dada pela Lei $\mathrm{n}^{\circ}$ 9.032, de 1995)

$\S 1^{\circ}$ A aposentadoria especial, observado o disposto no art. 33 desta Lei, consistirá numa renda mensal equivalente a $100 \%$ (cem por cento) do salário-de-benefício. (Redação dada pela Lei no 9.032 , de 1995)

$\S 2^{\circ}$ A data de início do benefício será fixada da mesma forma que a da aposentadoria por idade, conforme o disposto no art. 49.

§ 3ํㅗ A concessão da aposentadoria especial dependerá de comprovação pelo segurado, perante 0 Instituto Nacional do Seguro Social-INSS, do tempo de trabalho permanente, não ocasional nem intermitente, em condições especiais que prejudiquem a saúde ou a integridade física, durante o período mínimo fixado. (Redação dada pela Lei no 9.032, de 1995) § 4ํO segurado deverá comprovar, além do tempo de trabalho, exposição aos agentes nocivos químicos, físicos, biológicos ou associação de agentes prejudiciais à saúde ou à integridade física, pelo período equivalente ao exigido para a concessão do benefício. (Redação dada pela Lei no 9.032 , de 1995). [...]

\section{Informação previdenciária originária de textos simplificados}

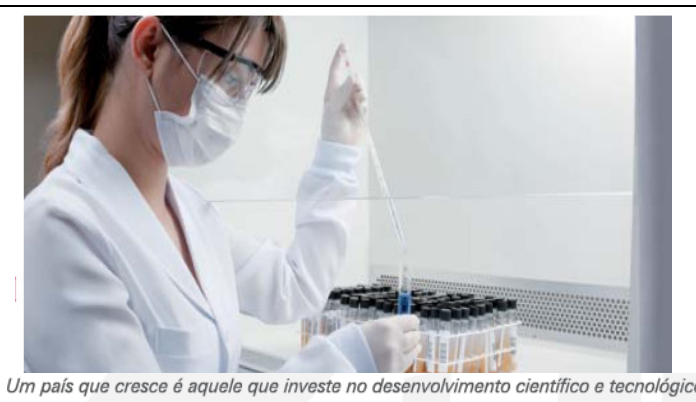

e no trabalhador da área. Foi por isso que a Previdência Social criou a aposentadoria especial, que beneficia o segurado e a segurada que trabalham em condições prejudiciais à saúde ou à integridade fisica.

\section{Quem tem direito}

Para ter direito à aposentadoria especial, além do tempo trabalhado, deverá ser comprovada a efetiva exposiçáo a agentes nocivos químicos, fisicos ou biológicos ou associação desses agentes prejudiciais à saúde ou à integridade física pelo período exigido para a concessẩo do beneficio, que é de 15, 20 ou 25 anos.

Atenção

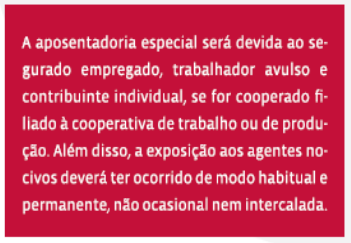

Curiosidade

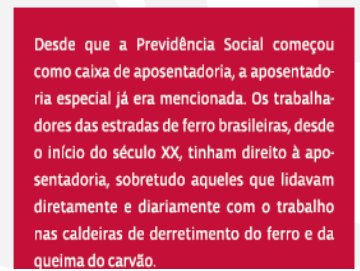

Fonte: Brasil (2012b, p. 28). 
O auxílio-doença e o salário-família, conforme quadros 5 e 6 também fazem parte dos benefícios cobertos pelo Regime Geral de Previdência Social. Analisando inicialmente o exemplo do auxílio-doença verifica-se o mesmo fenômeno ocorrido com a aposentadoria por invalidez. A redação do artigo 59, embora não tenha nenhum termo técnico-jurídico, tem a compreensão prejudicada devido à menção da expressão "período de carência exigido nesta Lei". Ademais, não há definição do que seja o auxílio-doença. De modo contrário, o texto da cartilha traz logo de início o que é auxílio-doença com uma redação favorável ao entendimento: "Auxilio doença é um benefício que todo segurado da previdência social recebe, mensalmente, ao ficar temporariamente incapacitado para o trabalho, por motivo de doença ou acidente". Observa-se que a redação está clara e objetiva.

O mesmo ocorre com a redação do texto que trata do saláriofamília: a cartilha mostra a preocupação do redator em apresentar inicialmente sua definição. Já a redação do texto legislativo, segue a tradição de fazer referências a outros dispositivos legais. Para conhecer toda a regulamentação do salário-família é necessário consultar os artigos 65 a 70. A disposição do texto e as ilustrações do folder simplificam o conteúdo desses cinco artigos. 


\section{Quadro 5 - Auxílio-doença}

\section{Informação previdenciária originária da Lei 8.213/91}

Art. 59. O auxílio-doença será devido ao segurado que, havendo cumprido, quando for o caso, o período de carência exigido nesta Lei, ficar incapacitado para o seu por mais de 15 (quinze) dias consecutivos. Parágrafo único. Não será devido auxíliodoença ao segurado que se filiar ao Regime Geral de Previdência Social já portador da doença ou da lesão invocada como causa para o benefício, salvo quando a incapacidade sobrevier por motivo de progressão ou agravamento dessa doença ou lesão. (...) trabalho ou para a sua atividade habitual

\section{Informação previdenciária originária de textos simplificados}

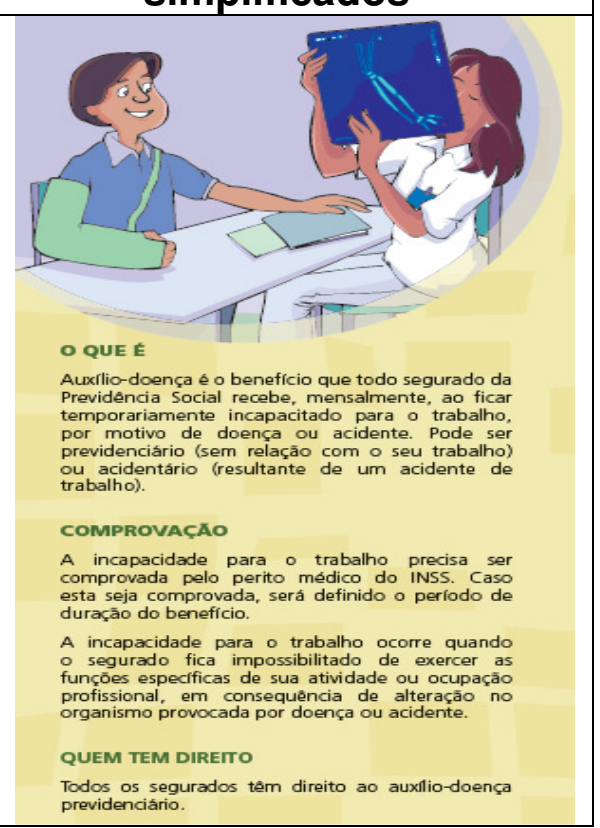

Fonte: Brasil (2014b).

Quadro 6 - Salário-família

\section{Informação previdenciária originária da Lei 8.213/91}

Art. 65. O salário-família será devido, mensalmente, ao segurado empregado, exceto ao doméstico, e ao segurado trabalhador avulso, na proporção do respectivo número de filhos ou equiparados nos termos do $\S 2^{\circ}$ do art. 16 desta Lei, observado o disposto no art. 66. (...)

Art. 67. O pagamento do salário-família é condicionado à apresentação da certidão de nascimento do filho ou da documentação relativa ao equiparado ou ao inválido, e à apresentação anual de atestado de vacinação obrigatória e de comprovação de freqüência à escola do filho ou equiparado, nos termos do regulamento. (Redação dada pela Lei $n^{0}$ 9.876, de 26.11.99)

Fonte: Brasil (2014e). 
O quadro 7 apresenta o benefício do auxílio-maternidade, que é regulamentado pelos artigos 71 a 73 da Lei 8.213/91. A redação do artigo 71 está clara, porém a explicação disponibilizada pelo folder no item "o que é" está mais objetiva. O que não pode passar despercebido neste exemplo é a desatualização do folder no que se refere aos dias de benefício que a segurada tem direito quando adota uma criança. Embora não se mencione a data de publicação no folder, tudo indica que ele foi publicado antes de 2013, ano em que houve a alteração legislativa. Cumpre destacar a importância da atualização frequente dos textos simplificados.

Quadro 7 - Salário-maternidade

\begin{tabular}{|c|c|}
\hline $\begin{array}{c}\text { Informação previdenciária } \\
\text { originária da Lei } 8.213 / 91\end{array}$ & $\begin{array}{c}\text { Informação previdenciária } \\
\text { originária de textos } \\
\text { simplificados }\end{array}$ \\
\hline $\begin{array}{l}\text { Art. 71. O salário-maternidade é devido à } \\
\text { segurada da Previdência Social, durante } 120 \\
\text { (cento e vinte) dias, com início no período } \\
\text { entre } 28 \text { (vinte e oito) dias antes do parto e a } \\
\text { data de ocorrência deste, observadas as } \\
\text { situações e condições previstas na legislação } \\
\text { no que concerne à proteção à maternidade. } \\
\text { (Redação dada pala Lei no } 10.710 \text {, de } \\
5.8 .2003 \text { ). } \\
\text { Parágrafo único. (Revogado pela Lei no 9.528, } \\
\text { de 1997) } \\
\text { Art. 71-A. Ao segurado ou segurada da } \\
\text { Previdência Social que adotar ou obtiver } \\
\text { guarda judicial para fins de adoção de criança } \\
\text { é devido salário-maternidade pelo período de } \\
120 \text { (cento e vinte) dias. (Redação dada pela } \\
\text { Lei no 12.873, de 2013). }\end{array}$ & 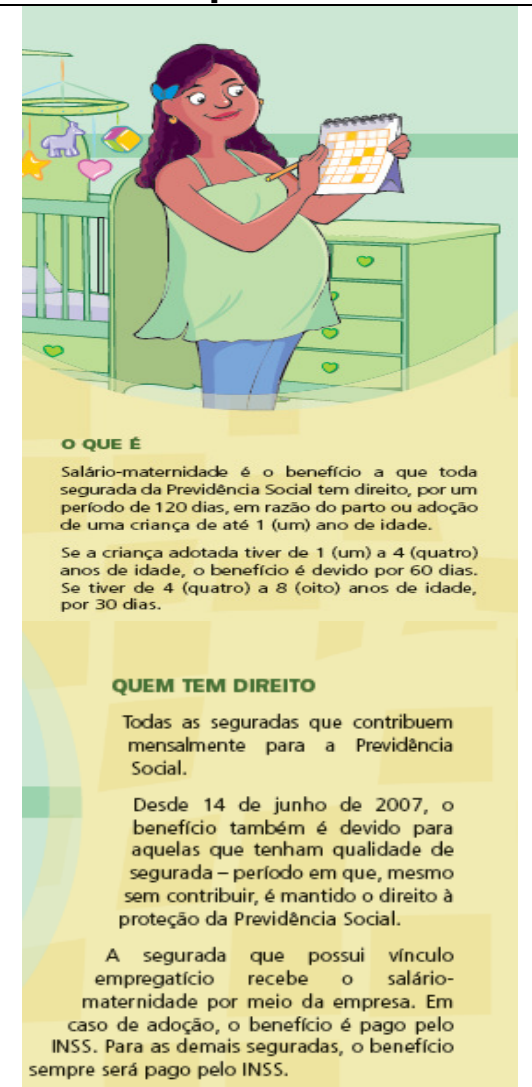 \\
\hline
\end{tabular}

Fonte: Brasil (2014f). 
Os próximos exemplos trazem os benefícios da pensão por morte e do auxílio-reclusão, que são regulamentados respectivamente pelos artigos 74 a 79 e 80 da Lei 8.213/91. A redação do artigo 74, conforme quadro 8 , está clara. O legislador diz que "a pensão por morte será devida ao conjunto dos dependentes do segurado que falecer", mas não está claro quem são eles. O segurado poderá encontrar alguns indícios nos artigos 76 e 77, porém de uma forma indireta: o parágrafo primeiro do artigo 76 cita o cônjuge e o parágrafo $2^{\circ}$ do artigo 77 menciona os filhos e irmãos. No folder são apresentados de forma objetiva quem são os dependentes do segurado que faleceu. $O$ mesmo ocorre com o auxílio-reclusão, conforme se verifica no quadro 9 . $O$ artigo 80 não deixa claro quem são os dependentes, já o texto do folder contempla essa informação.

Quadro 8 - Pensão por morte

\begin{tabular}{c|c}
$\begin{array}{c}\text { Informação previdenciária } \\
\text { originária da Lei } 8.213 / 91\end{array}$ & $\begin{array}{c}\text { Informação previdenciária } \\
\text { originária de textos simplificados }\end{array}$ \\
\hline
\end{tabular}

Art. 74. A pensão por morte será devida ao conjunto dos dependentes do segurado que falecer, aposentado ou não, a contar da data: (Redação dada pela Lei oํ 9.528, de 1997) I - do óbito, quando requerida até trinta dias depois deste; (Incluído pela Lei no 9.528 , de 1997)

II - do requerimento, quando requerida após o prazo previsto no inciso anterior; (Incluído pela Lei oㅡ 9.528, de 1997)

III - da decisão judicial, no caso de morte presumida. (Incluído pela Lei no 9.528 , de 1997)

(...)

Art. 77. A pensão por morte, havendo mais de um pensionista, será rateada entre todos em parte iguais. (Redação dada pela Lei № 9.032, de 1995)

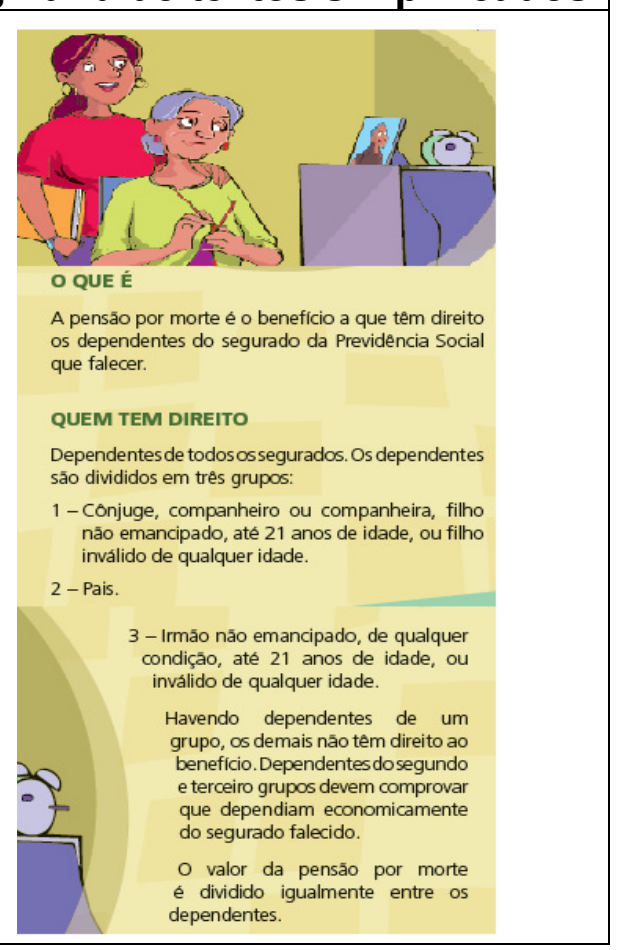

Fonte: Brasil (2014d). 


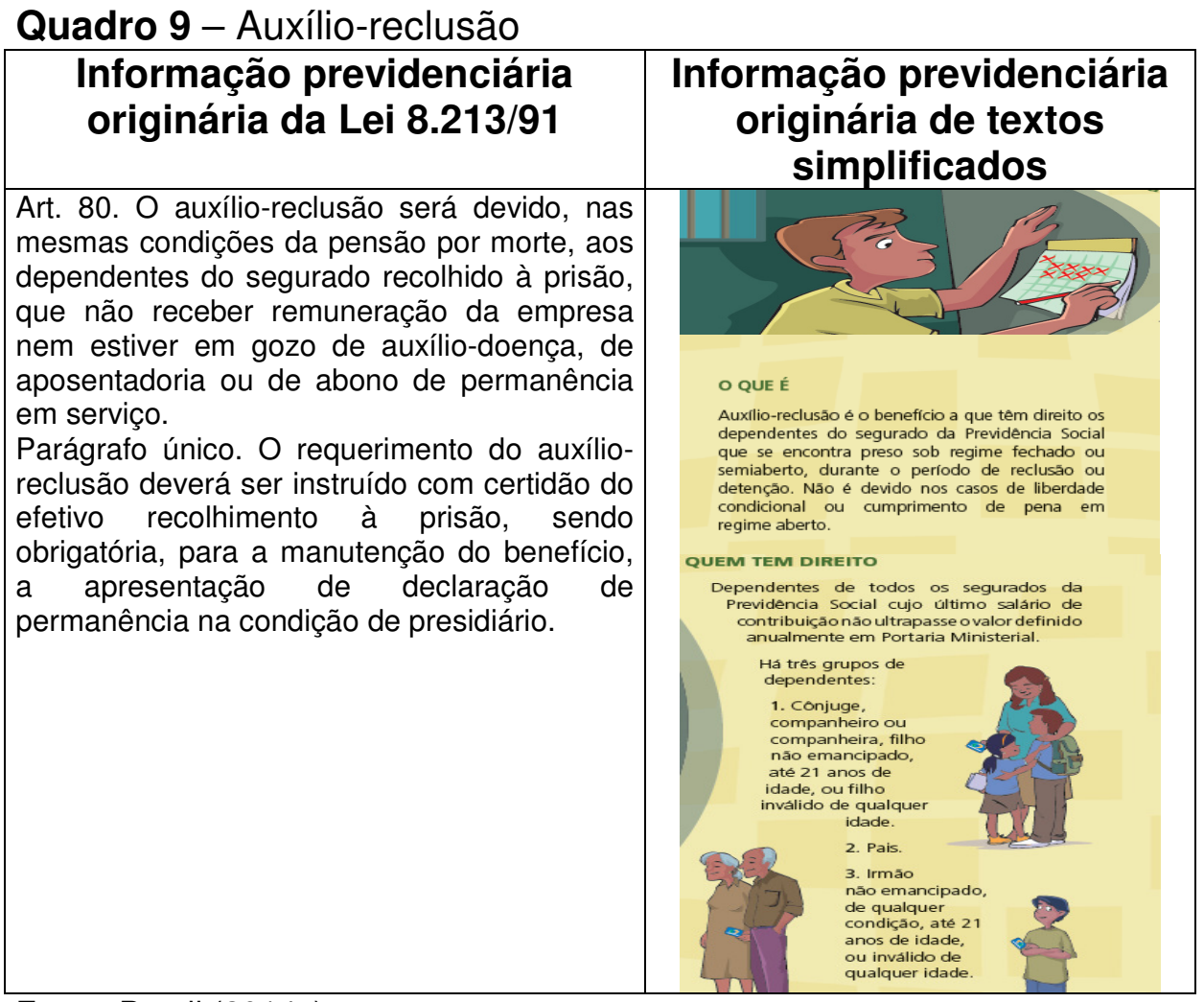

Fonte: Brasil (2014c).

O último benefício a ser analisado é o auxílio-acidente, conforme informações do quadro 10. O referido benefício é regulamentado pelo artigo 86 da Lei 8.213/91. Nota-se que o texto da lei está claro, embora tenha inversões de frases, de modo contrário, a redação do folder está mais objetiva e direta ao dizer que o auxílio-acidente é um benefício a que tem direito os "segurados e seguradas quando sofrem um acidente que resultem em sequelas que reduzem a capacidade de trabalho". A ilustração também auxilia a assimilação da informação pelo cidadão. 
Quadro 10 - Auxílio-acidente

\section{Informação previdenciária originária da Lei 8.213/91}

Art. 86. O auxílio-acidente será concedido, como indenização, ao segurado quando, após consolidação das lesões decorrentes de acidente de qualquer natureza, resultarem seqüelas que impliquem redução da capacidade para o trabalho que habitualmente exercia. (Redação dada pela Lei $n^{\circ}$ 9.528, de 1997).(...)

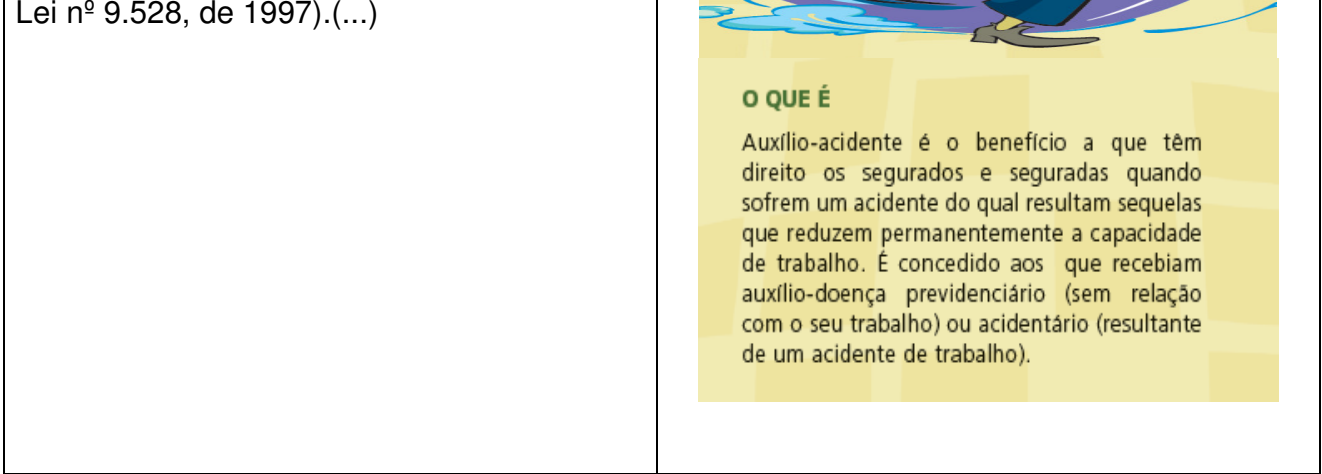

Fonte: Brasil (2014a).

\section{CONSIDERAÇÕES FINAIS}

As tecnologias da informação possibilitam a disseminação imediata e globalizada da informação e podem contribuir com a publicação de informações jurídicas para cidadãos que não possuem conhecimento técnico do Direito. Com a publicação da Lei de Acesso à Informação esta possibilidade ficou potencializada, uma vez que se exige das instituições governamentais a publicação de suas informações e serviços via internet e a criação de Serviços de Informação ao Cidadão.

A Lei de Acesso a Informação Pública equipara o Brasil a outras 90 nações que possuem leis que garantem a transparência pública, 0 acesso a documentos e a liberdade de informação. O dispositivo que exige que as informações disponibilizadas estejam em linguagem acessível e de fácil compreensão favorece as iniciativas que visam a simplificar a linguagem técnica para o não especialista.

No âmbito da legislação previdenciária há várias instituições 
governamentais e não governamentais que publicam textos ilustrativos sobre os benefícios garantidos pela previdência social.

A análise da Lei 8.213/91, comparada ao texto da cartilha e dos folders disponibilizados pelo portal do Ministério da Previdência Social, mostra que houve evolução no sentido de tornar acessível o conteúdo da legislação previdenciária antes mesmo da consolidação da LAI.

De um modo geral, as publicações estudadas seguem as recomendações da LAI, com textos que se caracterizam pela objetividade, clareza e uso de linguagem acessível. Os recursos ilustrativos utilizados também auxiliam a compreensão e assimilação da informação pelo cidadão. A única desvantagem das publicações simplificadas, em alguns casos, é a desatualização legislativa do texto. As leis brasileiras são alteradas constantemente e isto não pode passar despercebido. Sites, cartilhas, folders, boletins informativos e outras fontes que disponibilizam informação legislativa devem ter atualização constante.

Outro ponto a ser considerado em relação às cartilhas e folders é a falta de menção ao dispositivo legislativo que garante o benefício. É certo que o texto simplificado não deve repetir os termos técnicos da lei, pois desta forma não estaria cumprindo com seu objetivo, mas tais instrumentos também têm uma função pedagógica complementar: fazer com que o cidadão saiba que existe uma lei que garante os seus direitos. Isto pode amenizar o desconhecimento legislativo do brasileiro que, de uma forma geral, é bem moderado.

\section{REFERÊNCIAS}

BRASIL. Constituição da República Federativa do Brasil de 1988.

Disponível em:

<http://www.planalto.gov.br/ccivil_03/constituicao/ConstituicaoCompilado .htm>. Acesso em: 5 nov. 2015. 
BRASIL. Controladoria-Geral da União - CGU. Acesso à informação pública: uma introdução à Lei no 12.527, de 18 de novembro de 2011. Brasília, 2011a. Disponível em:

<http://www.acessoainformacao.gov.br/central-de-

conteudo/publicacoes/arquivos/cartilhaacessoainformacao.pdf>. Acesso em: 1 mar. 2014.

BRASIL. Decreto no 7.724, de 16 de maio de 2012a. Regulamenta a Lei no 12.527, de 18 de novembro de 2011, que dispõe sobre o acesso a informações previsto no inciso XXXIII do caput do art. 5o, no inciso II do $\S 30$ do art. 37 e no $\S 20$ do art. 216 da Constituição. Disponível em: $<$ https://www.planalto.gov.br/ccivil_03/_ato20112014/2012/decreto/d7724.htm>. Acesso em: 2 mar. 2014.

BRASIL. Lei no 12.527, de 18 de novembro de 2011b. Regula 0 acesso a informações previsto no inciso XXXIII do art. 5o, no inciso II do $\S 30$ do art. 37 e no $\S 20$ do art. 216 da Constituição Federal; altera a Lei no 8.112, de 11 de dezembro de 1990; revoga a Lei no 11.111, de 5 de maio de 2005, e dispositivos da Lei no 8.159, de 8 de janeiro de 1991; e dá outras providências. Disponível em:

<https://www.planalto.gov.br/ccivil_03/_ato2011-

2014/2011/lei/l12527.htm >. Acesso em: 2 mar. 2014.

BRASIL. Lei no 8.212, de 24 de julho de 1991a. Dispõe sobre a organização da Seguridade Social, institui Plano de Custeio, e dá outras providências. Disponível em:

<https://www.planalto.gov.br/ccivil_03/leis/L8212compilado.htm>. Acesso em: 2 mar. 2014.

BRASIL. Lei no 8.213, de 24 de julho de 1991b. Dispõe sobre os Planos de Benefícios da Previdência Social e dá outras providências. Disponível em:

<https://www.planalto.gov.br/ccivil_03/leis/L8213compilado.htm>. Acesso em: 2 mar. 2014.

BRASIL. Ministério da Previdência Social. Auxílio-acidente. Disponível em: <http://www.previdencia.gov.br/publicacoes/>. Acesso em: 4 mar. 2014a.

BRASIL. Ministério da Previdência Social. Auxílio-doença. Disponível em: <http://www.previdencia.gov.br/publicacoes/>. Acesso em: 4 mar. 2014b.

BRASIL. Ministério da Previdência Social. Auxílio-reclusão. Disponível em: <http://www.previdencia.gov.br/publicacoes/>. Acesso em: 4 mar. 2014c. 
BRASIL. Ministério da Previdência Social. Pensão por morte.

Disponível em: <http://www.previdencia.gov.br/publicacoes/>. Acesso em: 4 mar. 2014d.

BRASIL. Ministério da Previdência Social. Previdência social: com ela, você tem muito mais tranquilidade para sua vida e seu futuro. Brasília, 2012b. Disponível em: <http://www.previdencia.gov.br/publicacoes/>. Acesso em: 4 mar. 2014.

BRASIL. Ministério da Previdência Social. Salário-família. Disponível em: <http://www.previdencia.gov.br/publicacoes/>. Acesso em: 4 mar. 2014e.

BRASIL. Ministério da Previdência Social. Salário-maternidade. Disponível em: <http://www.previdencia.gov.br/publicacoes/>. Acesso em: 4 mar. $2014 f$.

BRASIL. Sistema Eletrônico do Serviço de Informação ao Cidadão - eSIC. Acesso a informação. Disponível em: <http://www.acessoainformacao.gov.br/sistema/site/index.html?ReturnUr l=\%2fsistema\%2fsite>. Acesso em: 5 out. 2015.

CARVALHO, José Murilo de. Cidadania na encruzilhada. In: BIGNOTTO, Newton (Org.). Pensar a república. Belo Horizonte: UFMG, 2000. p. 105-130.

JARDIM, José Maria. Lei de acesso à informação pública: dimensões político-informacional. In: ENCONTRO NACIONAL DE PESQUISA EM CIÊNCIA DA INFORMAÇÃO, 13., 2012, Rio de Janeiro. Anais... Rio de Janeiro, 2012. Disponível em: <obgi.files.wordpress.com/2012/10/jardimxiii-enancib.pdf>. Acesso em: 2 mar. 2014.

MARTINS, Sergio Pinto. Direito da seguridade social. 29. ed. São Paulo: Atlas, 2010.

MENDEL, Toby. Liberdade de informação: um estudo de direito comparado. 2. ed. Brasília: UNESCO, 2009. Disponível em:

$<$ http://www.acessoainformacao.gov.br/acessoainformacaogov/publicaco es/index.asp> . Acesso em: 2 mar. 2014.

UHLIR, Paul F. Diretrizes políticas para o desenvolvimento e a promoção da informação governamental de domínio público. Brasília: UNESCO, 2006. 
Andréia Gonçalves Silva; Marilda Lopes Ginez de Lara

Legibilidade da legislação previdenciária no contexto da lei de acesso à

informação

\section{Title}

Legibility social security legislation under the law of access to information

\section{Abstract}

Introduction: The Law on Access to Public Information (LAl) regulates the right to information established by the 1988 Federal Constitution, demanding that the government agencies ensure the right of access to public information through objective and agile procedures, in a transparent and clear way with easy to understand language. It is assumed that the laws made by the Legislative branch can be considered "public information" and therefore should be made available to the public in a simple and accessible format.

Objectives: To investigate initiatives which disseminate the social security legislation in accessible and easy to understand language for the citizen according to the arrangements of the Law on Access to Information.

Methodology: The content of the booklets available in the website of the Social Security Ministry was analyzed, being compared to the Law 8,231/91 arrangements - which provide the social security benefit plans - and observing if these publications are edited according to the LAI.

Results: In general, the writing and the illustrative features of the simplified texts - the booklets - bring easy understanding about the social security information for the citizen.

Conclusion: It is concluded that the studied publications follow the recommendations of $\mathrm{LAI}$, with texts characterized by objectivity, clarity and use of accessible language.

Keywords: Social security legislation. Access to Information Law. Booklets. Flyers.

\section{Titulo}

Legibidad la legislación seguro social bajo la ley de acceso a la información

\section{Resumen}

Introducción: La Ley de acceso a la información - LAl reglamenta lo derecho a la información establecido por la Constitución Federal de 1988, exigiendo que el gobierno garantice el derecho de acceso a la información pública a través de procedimientos y objetivos, en una lenguaje transparente, claro y fácil de comprender. Se supone que las leyes producidas por el legislador pueden ser consideradas "información pública" y por lo tanto deben hacerse disponibles al público en un formato simple y accesible.

Objetivo: Investigar las iniciativas que difunden la legislación de seguridad social de un modo accesible y fácil asimilación por el ciudadano, en conformidad con la Ley de Acceso a la Información.

Metodología: Fueran analizados los contenidos de los folletos disponibles en el sitio del Ministerio de Seguridad Social, comparándolos con lo dispuesto en la Ley 8.213/91, que dispone acerca de los planes de la seguridad social 
y comprobar si estas publicaciones se editan en conformidad con las disposiciones de la LAI.

Resultados: En general, la redacción y las características de los textos ilustrativos simplificados - folletos - facilitan la comprensión de la información de seguridad social por el ciudadano.

Conclusión: Concluimos que las publicaciones estudiadas siguen las recomendaciones de LAI, con textos que se caracterizan por la objetividad, la claridad y el uso de un lenguaje accesible.

Palabras clave: Legislación de seguridad social. Ley de Acceso a la Información. Cartillas. Folletos.

Recebido em: 16/03/2015

Aceito em: 03/08/2015 